\title{
Language Choice by the Student of the French Department, UNIMED
}

\author{
Andi Wete Polili ${ }^{1}$, Rabiah Adawi ${ }^{2}$, Zulherman ${ }^{3}$ \\ \{wetepolili_andi@yahoo.com ${ }^{1}$, rabiah.adawi@yahoo.co.id ${ }^{2}$, zulhermanghani@yahoo.com ${ }^{3}$ \} \\ Department of Languages and Arts, Universitas Negeri Medan, Indonesia ${ }^{1,2,3}$
}

\begin{abstract}
The objective of this research is to describe language choice by the Student of the French Department, FBS, UNIMED. To know the role relationships and speech situations in using appropriate language choice, to know the dominant language in use in the French Student Community at Unimed. In collecting the language choice data, the writer use questionnaires given to the French Students Department at Unimed. Language choice data was analysed based on the value scale used by previous researches, i.e. Fishman (1972), Siregar (1998) in the form of M (mean) and SD (standard deviations). The findings of the research are : The role relationships between student-Lecturer has criteria BI-BP (Indonesian=French), the speech situations "greeting" has criteria LBBP (more French than Indonesian), the most dominant language use in LBBI (more Indonesian than French), that this behaviour is very sensitive to cause code switching among the students.
\end{abstract}

Keywords: language choice, french, relationship.

\section{Introduction}

The usage of one language with another in a communication event often occurs. For example Indonesian is used interchangeably with French. Events like this are often in the case of the speaker and the other person conveying ideas, feelings, desires, and so on. The transition of language in such communication allows easier and smoother communication so that the expected goals can be achieved. In addition, the language transition is used by speakers and interlocutors with the aim that the use of language is more varied, interesting, and easily accepted.

French as a foreign language learned in Unimed requires students to communicate in that language as an endless community, the symptoms of code switching and choosing language are common symptoms that occur. The emergence of these symptoms is physically caused by the familiarity of the users in the foreign language, so that there is language contact here and there in them intentionally or not.

Basically the language used daily by UNIMED French students is Indonesian, but the reality is that as students learn French when they make communication, students often exchange code in their conversation by tucking between French and Indonesian in utterances they are in words, phrases, clauses, or sentences. In communicating between fellow students, both with classmates, classmates, seniors and lecturers determine which language choice to use and the code switching that occurs in conversations between them. Language events such 
as chatting, telling something, asking for help, greeting and discussing are explained in the realm of education among French students, UNIMED.

\subsection{Theoretical Bilingualism}

The concept of bilingualism has always undergone change and expansion since its introduction in the 20th century. Bloomfield (1993: 56) provides limits on bilingualism as two languages mastery like native speakers. Weinreich (1968: 1) interpreted it as the practice of using two or more languages alternately by the same individual. Haugen (1953: 7) says that bilingualism is the ability to issue meanings in other languages. Every time the concept of bilingualism is further softened so that it often only means passive mastery of written language only. Mackey (1970: 555) himself explained it as alternating use of two languages or more by the same person.

\subsection{Language Choice}

Language choice is a manifestation and use of a particular language by a bilingual person after he decides to choose one language to respond to a particular event. In language selection, many factors influence it. Some of them are the factors of participants, situation, domain, topic of conversation, place, language that is mastered, the form of language and others (ancient, 1997). Holmes (1992: 23) member example, namely; anahina a Tongan New Zealander bilingual speaker lives in Auckland. At home, he used Tongan to his parents and grandmother, but with his brother, he used English when talking about school and their schoolwork.

\subsection{Domain and Role Relations}

According to Siregar (1995: 38) the realm is a cluster of situations or interaction horizons where one language is used in the domain associated with a particular variation, where the variations are compared to the social situation and are abstractions of the cross between the relationship of roles and status, environment and certain subjects. The domain is bounded by Fishman (1972: 24) as an institutional context and appropriate behavioral events that occur together. The realm will explain to us why the language chosen by the speaker is in accordance with the topic, the role of each speaker and the place where the incident happened. The suitability between language choices and the three factors above is then linked to the social cultural norms prevailing in the speaking community. Fishman (1972: 22) cites Greenfield's (1968) proposition which proposes five kinds of domains that encourage speakers to choose languages according to topics, roles and places, namely family, domain, friendship, religious domain, education domain, and job domain. Holmes (1992: 225) member example: maria is a teenager, her parents are Portuguese dating to London. He uses Portuguese at home and in the Portuguese church to an older person, but he uses English at school and at café with his friend.

\subsection{Code Switching}

Scotton (1970) also summarizes the opinions of previous sociolinguists about the causes of code switching, namely:

1) Lack of knowledge or lack of ease in using certain languages to discuss a topic causes someone to switch code from one language to another.

2) Speech participants want to hide what they are talking about from the third person present. 
3) Used as a tool to show changes in the tone of conversation from a familiar tone to an official tone.

4) To give an impression to the person he is talking to that he is capable of using various languages, or at least one prestige language.

Code switching can come from language skills, it can also come from the ability to communicate. If the code switching is not yet working properly, then the symptoms come from language skills, but if he is present because the speaker has become accustomed to using mixed language for mere convenience, then the symptoms clearly originate from the ability to communicate. Lance described it as if the words were at the end of the tongue to say. Lance (Haugen, 1978: 33) ruled out the notion that code switching was caused by insufficient language skills of a bilingual person. $\mathrm{He}$ is more inclined to justify the opinion that bilingualists switch code in a relaxed conversation, where any speech elements closer to the tip of the tongue will be spoken more easily. The ease of speaking of speakers as a source of code switching when speakers speak in A, is tucked away. phrases like words, phrases or clauses in language B as well as vice versa. This is usually caused solely because the mastery of the language of the speaker is less than perfect. Any language that is easiest because it is used to being spoken is what will be said.

\section{Research Method}

This type of research is a combination of qualitative and quantitative. Quantitative research according to Moleong (Djadjasudarma, 1993: 9) involves calculations or numbers Qualitative research according to Djadjasudarma (1993: 10) is a procedure that produces descriptive data in the form of written or oral data in the language community. Regarding the method used by the author is a descriptive method according to Surakhmad (1980: 139) that researchers try to describe and analyze data starting from the collection stage, data compilation is accompanied by analysis and interpretation of the data. This research was conducted in the field involving students who were learning French as an informant. This research was conducted at the Medan State University, the Indonesian Education University and the Jakarta State University. In this study, the authors conducted data collection techniques using questionnaire distribution. Respondents were given twenty questions about the use of the language they use when interacting on role relationships, for example between studentlecturers and language events such as chatting in the realm of the Unimed French student community.

\subsection{Data Analysis}

After the data has been collected and analyzed, the results of the study are obtained from the chosen language and the UNIMED French student code expert as follows:

\subsection{Language Choice}

In the data select this language, the results obtained from the relationship of language roles and events are obtained. In table 1 shows the mean and standard deviation for each role relationship of UNIMED French students as follows: 
Table 1.The mean and standard revisions for each role relationship.

\begin{tabular}{llll}
\hline Role relationships & $\mathrm{M}$ & SD & Usage of Language \\
\hline Classmate & 2,84 & 0,19 & LBBI \\
Lecturer & 3,08 & 0,21 & BI = BP \\
Juniors & 2,33 & 0,16 & LBBI \\
Seniors & 2,54 & 0,17 & LBBI \\
\hline
\end{tabular}

LBBI $=$ More Indonesian than French

$\mathrm{BI}=\mathrm{BP}=$ Indonesian $=$ French

From the results of this study, it was obtained a role relationship with lecturers (studentlecturers) who have Mean $=3,08$ while the other role relationships have almost the same mean. While the Standard Deviation is statistical information. The higher the elementary school, the more spread the data and the lower the elementary school, the more uniform the data. Among these choices, the role relationship with the lecturer seems to have the highest $\mathrm{SD}$ of other role relationships indicates that the spread of variation in data in the role relationship with the highest lecturers of other role relationships.

Table 2.shows the mean and standard deviation for the following language events:.

\begin{tabular}{llll}
\hline Language Events & M & SD & Usage of language \\
\hline Chatting & 2,32 & 0,17 & LBBI \\
Tell something & 2,36 & 0,18 & LBBI \\
Ask for help & 2,44 & 0,18 & LBBI \\
Greeting & 4,01 & 0,30 & LBBP \\
Discuss & 2,36 & 0,18 & LBBI \\
\hline
\end{tabular}

LBBI $=$ More Indonesian than French

$\mathrm{LBBP}=$ More French than Indonesian

Table 2 shows the mean and standard deviation in language events with the highest value 4,01 to greet and the lowest with a value of 2,32 to mingle. Tell something and discuss gets a value of 2,44 . Among these choices, the language event greeting has the highest elementary school than others indicating that the spread of data variations in language events addresses the highest of other language events.

Table 3 shows the mean and standard deviation for each role relationship in each language event are as follows: 
Table 3.Mean and standard deviation for each role relationship in each language event.

\begin{tabular}{llllll}
\hline & \multicolumn{5}{c}{ LANGUAGE EVENTS } \\
\hline Role relationships & Chatting & Tell & Ask for & Greeting & Discuss \\
& something & help & & \\
& M & M & M & M & M SD \\
Classmate & SD & SD & SD & SD & \\
& 2,32 & 2,66 & 2,66 & 4,07 & 2,52 \\
Lecturer & 0,34 & 0,40 & 0,40 & 0,61 & 0,37 \\
& 2,77 & 2,52 & 2,68 & 4,60 & 2,84 \\
Juniors & 0,41 & 0,37 & 0,40 & 0,70 & 0,42 \\
& 1,93 & 2,02 & 2,02 & 3,73 & 1,95 \\
Seniors & 0,29 & 0,30 & 0,30 & 0,56 & 0,29 \\
& 2,30 & 2,23 & 2,41 & 3,64 & 2,14 \\
& 0,34 & 0,33 & 0,36 & 0,54 & 0,32 \\
\hline
\end{tabular}

The mean value from table 3 above, the lowest is the relationship between the role of classmates in chatting with a score of 1,93 and the highest value is the role relationship with the lecturer who greets a value of 4,60 .

Table 4 below, is the range of the most dominant language use by UNIMED French students as follows:

Table 4.Range of language usage.

\begin{tabular}{llll}
\hline Usage of language & Value & Amount & $(\%)$ \\
\hline Always Indonesian & 1 & 141 & 16,02 \\
More Indonesian & 2 & 294 & 33,41 \\
Indonesian and & 3 & 232 & 26,36 \\
French are the same & & & \\
More French & 4 & 115 & 13,07 \\
Always French & 5 & 98 & 11,14 \\
\multicolumn{1}{c}{ Total } & & 880 & 100 \\
\hline
\end{tabular}

In the table above, obtained the use of languages (more languages of Indonesia) with the highest value $33.41 \%$, Indonesia and French language just as much that amounted to $26.36 \%$, while the lowest value is the use of a language (always a language France) with a value of $11.41 \%$. So there are relationships that are the most prominent is LBBI, this corresponds to the behavior of select language above, with behavior like this, the symptoms instead of the code is very vulnerable. Select the language of patterns such as these are the most prominent matrix is the language of Indonesia. 


\section{Discussion}

\subsection{Language Choice}

Table 1 shows the mean role relationship with the lecturer who got a mean value of 3.08 is the highest value which means BI = BP (the use of Indonesian-French is the same). As for the role relationships with classmates, classmates, and seniors who get an average score of 2, which means LBBI (more Indonesian than French) so there is no prominent difference between the three relationships above. So the behavior of choosing BI = BP language is the existence of coercion or fear of the lecturer to require students to speak French and Indonesian in the same language.

Table 2 shows the mean language event greeting is the highest number, 4.01 which means LBBP (more French than Indonesian), while other language events such as chatting, telling something, asking for help and discussing get an average score of 2, which means LBBI (more Indonesian) so that there are no prominent differences between the four language events. The event of language greeting is considered to be a conversation that has been attached and is more familiar or easy to say by Unimed French students.

Table 3 shows the mean in each role relationship in each language event is the role relationship with the lecturer in the greeting language event gets a score of 4.60, which means LBBP (more French), while for the role relationship with the younger class in a language communication event is 1, 93, which means SBI (always Indonesian).

Table 4 shows the tendency of students to use LBBI (more Indonesian than French) which amounted to $33.41 \%$, followed by $\mathrm{BI}=\mathrm{BP}$ (as many as Indonesian with French) totaling $26.36 \%$, SBI (always Indonesian) totaling 16.2\% \%, LBBP (more French than Indonesian) $13.07 \%$ and the lowest is SBP (always in French) which amounts to $11.14 \%$. LBBI's behavior is caused by a lack of vocabulary, less supportive motivation and laziness to speak French. So LBBI's behavior has the potential to create code switching symptoms in Indonesian-language conversations. So, French students in UNIMED tend to use more Indonesian in everyday conversation.

\section{Conclusion}

Based on the results of the analysis and discussion in this study, conclusions can be drawn, namely:

1. The results of the questionnaire using select language are that: In terms of the role relationship, the role relationship with the lecturer is the highest mean value that amounts to 3.08, which means BI = BP (Indonesian and French) as much, this indicates that the role relationship with the lecturer determines which language to use. Whereas the other role relationships are with classmates, younger siblings, seniors having an average value that is almost the same, which is 2 which means LBBI (more Indonesian), so these three role relationships do not have very significant differences. The role relationship with the lecturer indicates that there is coercion and fear of the lecturer so that it requires students to speak French. In terms of language events, language events greet the highest average score of 4.01, which means LBBP (more French). While other language events such as chatting, telling something, asking for help and discussing have an average value of almost the same, which means that LBBI (more Indonesian) is used in everyday conversations in the UNIMED 
environment among French students. This event of greeting language indicates that the word is already very attached, familiar and easily spoken by the speaker.

2. In terms of the percentage of language usage, the most dominant language use is LBBI (more Indonesian) which is $33.41 \%$. So, UNIMED French language students tend to use Indonesian more. While the lowest language use is always French which amounts to $11.14 \%$. With this LBBI behavior the symptoms of code switching are very vulnerable or prominent which occur in Indonesian language by UNIMED French students.

\section{Reference}

[1]Appel, Rene dan Pieter Musyken. 1986. Language Contact and Biligualism. Amsterdam : Edward Arnold.

[2]Ardial, 2001. Metode Penelitian Sosial. Medan: UMSU

[3]Arikunto, Suharsimi. 1997. Prosedur Penelitian: Suatu pendekatan Praktek. Jakarta: PT. Rineka Cipta.

[4]Diebold, A.R.Jr.1964. Incipient Bilingualism.InHymes. 1964. Language in Culture and Society. New York :Herper and Row.

[5]Fishman, J.1970. Readings in the sociology of language.Paris : Mouton.

[6]Gumperz, J. 1968. The speech Comunnity Language and Social context.InGiglioli, 1972.Language and Social context.Harmondsworth : Penguin.

[7]Hymes. Dell. 1964. Language in Culture and Society. New York : Harper and Row.

[8]Nababan, P.W.J. 1993. Sosioliguistik.Jakarta : PT. Gramedia.

[9]Rayfield, J.R. 1970. The languages of a bilingual community. The Hague : Mouton.

[10]Weinreich, Uriel. 1968. Language In Contact Findings and Problems. Paris : Mouton. 